\title{
E-LEARNING READINESS AMONG STUDENTS OF DIVERSE BACKGROUNDS IN A LEADING MALAYSIAN HIGHER EDUCATION INSTITUTION
}

\author{
${ }^{1}$ Donnie Adams, Bambang Sumintono, Ahmed Mohamed \& \\ Nur Syafika Mohamad Noor \\ Institute of Educational Leadership, Faculty of Education \\ University of Malaya, Malaysia
}

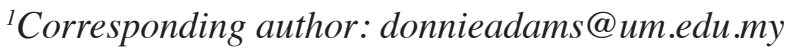

Received: 27 March 2018 Revised : 8 November 2018 Accepted: 21 November 2018

\begin{abstract}
Purpose: Blended learning is rapidly emerging as a domain for practice and research. Across disciplines and contexts, at individual instructor and institution levels, educators are experimenting with the blended learning model of instruction. The current generation of learners have been referred to as 'digital natives' in reflection of their apparent ease and familiarity with digital technology. However, questions remain about how ready students are for a blended learning model of instruction. The purpose of the study was to investigate students' readiness for a blended learning model of instruction in a leading Malaysian higher education institution.
\end{abstract}

Methodology: The study employed a non-experimental quantitative research design. Data were gathered from a sample of 235 undergraduate and 131 postgraduate students using the Blended Learning Readiness Engagement Questionnaire (BLREQ). The data was analysed using the WINSTEPS Rasch model measurement software to determine the validity and reliability of the instrument. Differential Item Functioning (DIF) analysis was also used to identify responses based on students' demographic profiles.

Findings: Findings identified that students were ready for blended learning. Further analysis indicated that there were differences in students' readiness for blended learning based on gender, age, ethnicity, field of study, and level of education. 
Significance: This study provides insights on students' readiness towards blended learning, particularly in the Malaysian context, discusses implications for blended learning practices in higher education institutions, and offers recommendations for future research.

Keywords: Blended learning, E-learning, gender differences, student diversity, higher education institution.

\section{INTRODUCTION}

The past decade has seen the world of tertiary education evolve with the rapid development in internet technologies, and revolution in computer softwares (Tayebinik \& Puteh, 2012). This has revolutionised the way learning and teaching is enacted, particularly in distance education. Emerging concepts such as online learning or e-learning, which are largely used in the higher education arena, have led to a flurry of comparative studies done on e-learning and face-to-face learning environments (Northey et al., 2015; Southard, Meddaug \& Harris, 2015), students' learning outcomes (Bernard et al., 2014; González-Gómez et al., 2016; Ryan et al., 2016), and e-learning's strengths and weaknesses (Wang, 2010).

E-learning environments do present some disadvantages, such as inhibiting face-to-face communication and socialising among the learners, resulting in the emergence of a new learning environment, termed blended learning (Tayebinik \& Puteh, 2012). Blended learning combines concepts from both e-learning and the face-to-face learning environment (Azizan, 2010). As a result, the application of blended instruction among lecturers in higher education institutions has quickly gathered pace as they believe varied delivery methods would enhance students' learning experiences and their learning outcomes (Lim \& Morris, 2009).

However, despite its possibilities, the main question remains how ready students are for a blended learning model of instruction. Students struggle to adapt to the change from traditional classrooms to virtual classrooms (Sanchez-Gordon \& Luján-Mora, 2014), higher education institutions lack the neccessary facilities and amenities, such as high-speed internet connections (Panyajamorn et al., 2018), 
and students lack computer literacy skills and motivation (Garrison \& Anderson, 2003).

\section{LITERATURE REVIEW}

\section{E-Learning}

Electronic learning, or commonly known as e-learning, is among the earliest applications of web-based technology (Azhari \& Ming, 2015). E-learning is defined as the delivery of learning using purely Internet and digital technology (Al-Busaidi, 2013). It uses a computer and software programs for its learning process, and was first designed for working adult students who were unable to receive formal education as full-time students (Moore, Dickson-Deane \& Galyen, 2011).

Today, the functionality of e-learning has expanded to include all types of students, regardless of whether they're studying full time, part time, or distance learners in higher education institutions (Azhari \& Ming, 2015). Since 2012, Massive Open Online Courses (MOOCs) have been said to be the new form of e-learning for millions of people, with a growing number of universities and private organisations offering them worldwide (Margaryan, Bianco \& Littlejohn, 2015). MOOCs are now endorsed as a major advancement in higher education.

In the Malaysian context, higher education institutions began implementing e-learning in the late 1990s (Hussin, Bunyarit \& Hussein, 2009). At the time, there were execution issues such as the lack of trained lecturers, facilities and infrastructures, students' preparedness, and students' resistance to adopt e-learning and the Learning Management System (LMS) tools (Azhari \& Ming, 2015). Nonetheless, its demand continued to rise due to its capablity to reach global audiences, and its unique functionality, accessibility and flexibility in the long run (Azhari \& Ming, 2015).

However, there are persistent concerns about the quality of e-learning relative to a face-to-face learning environment (Panyajamorn et al., 2018). Paechter and Maier (2010), in their study, found that Austrian students still preferred face-to-face learning for communication 
purposes, and the preservation of interpersonal relations. Another study by Orton-Johnson (2009) in the UK found that students did not accept online materials, and preferred traditional text materials as the medium for their education.

On the contrary, in Bernard et al.'s (2014) meta-study, students in blended programmes achieved better results than students in traditional classrooms. Similar results were found in other studies, for example, Northey et al. (2015), Ryan et al. (2016), Southard, Meddaug and Harris (2015), and González-Gómez et al. (2016). In Malaysia, Lau and Shaikh (2012) found that students' computer and internet efficacy, and personal characteristics such as gender, ethnicity, course year level and financial aid status resulted in a significant difference in students' e-learning readiness.

\section{Blended Learning in Higher Education Institutions}

As defined earlier, blended learning combines both online learning and face-to-face instruction (Graham, 2013). Research on blended learning has increased over the past decade, with much of the work focused in tertiary education contexts (Halverson et al., 2012) due to its transformative potential in education (Graham \& Robison, 2007). Consequently, it is claimed that blended learning is "likely to emerge as a predominant model of the future - and to become far more common than either [online or face-to-face instruction] alone" (Watson, 2008, p. 3).

In line with these educational developments, one of the main initiatives of the Malaysian Ministry of Education under the Malaysian Education Blueprint 2015-2025 (Higher Education) is the use of Blended Learning (BL) as a conduit for transforming existing pedagogy. "Blended learning models will become a staple pedagogical approach in all HLIs [Higher Learning Institutions]. Key initiatives include: Making online learning an integral component of higher education and lifelong learning, requiring up to $70 \%$ of programmes to use blended learning models" (Malaysian Education Blueprint 2015-2025 (Higher Education): E-16).

Lending their support to the Ministry's initiatives, Malaysian higher education institutions are now required to integrate e-learning systems, or better known as Learning Management Systems (LMS), 
in their courses and face-to-face instruction, creating a 'blended learning' environment for their students (Tayebinik \& Puteh, 2012). The LMS software is a popular approach for planning, delivering, and managing blended learning models of instruction in higher education institutions (Martinez \& Jagannathan, 2012). LMS, such as Moodle and Blackboard, provide tools to enable communications between lecturers and students online, track student activities, such as assignment submissions, discussion management, group work, and other administrative tools (Pellas \& Kazanidis, 2015). Embi et al. (2011) reported that the most widely used LMS components in all Malaysian higher education institutions are communications, followed by course delivery, productivity, content development, and administration. However, only a few higher education institutions had LMS features that encouraged students' involvement, such as group work, and portfolio.

Initial research into blended learning focused on defining the term, and identifying the benefits and challenges it offers. As the research field matured, the focus of research moved to student learning outcomes, the interaction in these environments, and student perceptions and experiences (Drysdale et al., 2013). Drysdale et al. (2013) suggested that research on the readiness for blended learning from the students' point of view is a way to evaluate the success and effectiveness of blended learning. Baldwin-Evans (2006), in the same vein, supported the idea that, prior to even considering the full implementation of the blended learning model of instruction, assessing students' readiness was of utmost importance.

\section{Students' Readiness for Blended Learning}

Many researchers have reported on the benefits and advantages of blended learning (Heidi \& Neo, 2015; Doiron \& Asselin, 2011; Azizan, 2010). However, there are a few notable concerns as the venture into blended learning intensifies. Students might struggle in adapting to this initiative as they now must lead their own learning process (Vaughan, 2007). Other students might find it difficult to adjust to the online course structure (Tayebinik \& Puteh, 2012).

In a study by MacKeogh (2003), only $12 \%$ of students opted for e-learning, while $20 \%$ of the students preferred the traditional form of learning. These results indicate that, even though students were 
advocates of technology, many of them were unwilling to forgo the face-to-face learning experience. In another study, Howard (2009) found that students in e-learning modules missed the face-to-face interaction with their lecturers and other coursemates. Starenko et al. (2007) found that students faced a great challenge working with each other in an online environment. On the contrary, findings by Lopez-Perez et al. (2011) found that tertiary students seemed to prefer online learning as a complement to traditional modes of classroom teaching.

While blended learning creates flexible learning for students, it's unclear in the literature on which aspects enable them to experience maximum benefits. Different factors have been studied extensively to determine students' online learning experience (Shahnaz \& Hussain, 2016). For instance, Yukselturk and Bulut (2007) focused on gender, age, motivational beliefs, and self-regulated learning. Rhee et al. (2007) focused on technological readiness. Abbas et al. (2011) explored the roles of technical infrastructure, organisational factors (organisational rules and culture), and social readiness factors (governmental rules, and administrative instructions).

Students' readiness is another powerful factor in implementing online learning successfully (Rasouli, Rahbania \& Attaran, 2016; Mosadegh, Kharazi \& Bazargan, 2011). Readiness can be studied by assessing students' knowledge (George et al., 2014), technology skills (Seraji \& Yar Mohammadi, 2010; George et al., 2014; Rasouli, Rahbania \& Attaran, 2016), technology availability (Anene, Imam \& Odumuh, 2014; Rasouli, Rahbania \& Attaran, 2016; Seraji, 2010), self-directed learning (Chu \& Tsai, 2009; Kaur, 2014), computer and internet efficacy (Seraji, 2013; Kumar, 2017), and attitude (Hussein, 2010; George et al., 2014; El-Gayar, Moran \& Hawkes, 2011; Kumar, 2017) in e-learning.

While much is now known about online learning, there is still a lack of research and rich descriptions on students' readiness towards a blended learning environment. The combination of both e-learning and the face-to-face learning environments may result in student disengagement in the blended learning model of instruction. Park (2009) suggested that higher education institutions need to assess their students' readiness for blended learning for them to successfully embrace the blended learning environment. Harris et al. (2009) further reiterated this importance by highlighting the perspectives of students as the most vital component. By reviewing the literature, 
students' readiness for blended learning can be categorised into six main factors: a) technology skills; b) technology usage; c) technology availability; d) self-directed learning; e) computer and internet efficacy, and f) students' attitude towards blended learning. Therefore, this study aimed to investigate students' readiness for blended learning, and specifically assess any significant differences between students' gender, age, ethnicity, field of study, and level of education, and their readiness for blended learning.

\section{RESEARCH QUESTIONS}

Following the discussion on e-learning, blended learning in higher education institutions, and students' readiness for blended learning, two research questions guide this paper:

(1) What is the level of students' readiness for blended learning in a leading Malaysian higher education institution?

(2) Are there any significant differences in students' readiness for blended learning based on gender, age, ethnicity, field of study, and level of education?

\section{METHODOLOGY}

\section{Participants}

The research used a quantitative approach, where students' blended learning readiness was treated as a variable that can be measured by a questionnaire. This study employed a cross-sectional quantitative survey method. A sample of 235 undergraduate $(64.21 \%)$ and 131 postgraduate $(35.79 \%)$ students from various fields of study were selected from a public higher education institution in Kuala Lumpur, Malaysia. Convenience sampling technique was used, where respondents were administered hard copy questionnaires by the researchers personally, as well as an online survey administered via the university's student mailing list. The study was conducted in November 2017. With regards to ethical consideration, the students' consent to take part in this study was sought first before they filled in the questionnaire. Participation was strictly voluntary and anonymous. The demographic profile of the respondents is indicated in Table 1. 
Table 1.

Demographic Profile of Respondents $(N=366)$

\begin{tabular}{lcc}
\hline Demographics & Respondents & Percentage (\%) \\
\hline Gender & & \\
Male & 156 & 42.62 \\
Female & 210 & 57.38 \\
Age & & \\
19 years and below & 88 & 24.04 \\
20-29 years & 176 & 48.09 \\
30-39 years & 59 & 16.12 \\
40-49 years & 34 & 9.29 \\
50-59 years & 8 & 2.19 \\
Over 59 years & 1 & 0.27 \\
Ethnicity & & \\
Malay & 181 & 49.45 \\
Chinese & 95 & 25.96 \\
Indian & 36 & 9.84 \\
Bumiputera & 16 & 4.37 \\
International & 38 & 10.38 \\
Level of Education & & \\
Undergraduate & 235 & 64.21 \\
Postgraduate & 131 & 35.79 \\
Field of study & & \\
Social sciences & 186 & 50.82 \\
Sciences & 43 & 11.75 \\
Engineering & 50 & 13.66 \\
Medicine & 87 & 23.77 \\
\hline
\end{tabular}

\section{Instrumentation}

A Blended Learning Readiness Engagement Questionnaire (BLREQ) was developed to gauge students' readiness for blended learning in a public higher education institution in Kuala Lumpur, Malaysia. The BLREQ contained five basic demographic questions (i.e. age, gender, ethnicity, field of study, and level of education), and 41 items in six dimensions which addressed various aspects of students' readiness for blended learning. The six dimensions, along 
with the respective number of items in the questionnaire are as follows: technology skills (11 items), technology usage (8 items), technology availability (4 items), self-directed learning (6 items), computer and internet efficacy (8 items), and attitude (4 items). A 4-point Likert-type scale ranging from strongly disagree (1) to strongly agree (4) was provided as response options for all the items. Only one response was allowed per item.

Prior to the actual data collection, a small-scale pilot test was conducted with 30 students in a public higher education institution in Kuala Lumpur, Malaysia to ensure the suitability of wordings, formatting, and layout. These 30 students were excluded from the main study.ARasch measurement model software named WINSTEPS version 3.73 was used to determine the validity and reliability of the instrument. Through its calibration of item difficulties and person abilities, the WINSTEPS software mathematically transformed raw ordinal data (Likert-type data), based on frequency of response which appeared as probability, to become logit (log odd unit) via the logarithm function, which assesses the overall fit of the instrument as well as person fit (Linacre, 2012; Bond \& Fox, 2015).

Table 2 displays the internal reliability scores of the instrument (source Appendix 3). These scores refer to the fit statistics or the reliability indices reported in logit measures that determine the overall quality of the BLREQ, and the psychometric properties of the instrument.

Unidimensionality and Rating Scale Analysis

The BLREQ instrument had a good unidimensionality measure (Appendix 1), where index of raw variance was above the standard of $40 \%$ (Fisher, 2007). This means that the instrument can effectively measure blended learning readiness. Rating scale analysis (Appendix 2) informed that the four rating scale given to respondents, from strongly agree to strongly disagree, was easily understood with a threshold rating scale of 1.4 to 5.0 (Fisher, 2007).

Person Reliability and Item Reliability

According to Table 2, the 'real' Person Reliability index (0.94) indicates that the consistency of person responses was 'very good' (Sumintono \& Widhiarso, 2014). This implies that the 
scale discriminates very well between persons. The same logic of interpretation applies to the Item Reliability measures of 0.99 , which is also classified as 'very good' (ibid). This suggests that the probability of persons responding to items were likely to be high. High Item Reliability estimates also suggest that the items defined the latent variable very well (Bond \& Fox, 2015). As such, the BLREQ may be regarded as a reliable instrument for use with different groups of respondents.

\section{Cronbach Alpha}

The value of the Cronbach Alpha coefficient (0.97), according to the Rasch Model computation, described the interaction between the 366 persons and the 41 items. The reliability score of 0.97 is classified as 'very good', as described under the instrument quality criteria in Sumintono and Widhiarso (2014). This score suggests that there was a high level of interaction between the persons and items. An instrument having very good psychometric internal consistency is considered a highly reliable instrument.

\section{Person and Item Separation Index}

Person Separation index is an estimate of how well the BLREQ can distinguish between 'Person abilities' in terms of the latent trait. The bigger the separation index, the more likely the respondents will respond correctly to the items. On the other hand, the Item Separation index indicates how wide spread the items are in defining both the easy and difficult items (Boone et al., 2014). The wider the spread, the better the fit. In this study, the Person Separation index (4.00), and the Item Separation index (9.01), as shown in Table 2 below, clearly indicate the BLREQ's good spread across the range of respondents and items. These criteria endorse the BLREQ as a fit and reliable instrument for identifying students' readiness for blended learning.

Table 2

Reliability of Person and Item

\begin{tabular}{lcccc}
\hline & Mean Logit (SD) & Separation & Reliability & Alpha Cronbach \\
\hline Person & $2.04(1.67)$ & 4.00 & 0.94 & 0.97 \\
Item & $0.00(0.99)$ & 9.01 & 0.99 & \\
\hline
\end{tabular}




\section{Data Analysis}

For data analysis, SPSS version 25, and a Rasch model measurement software, WINSTEPS version 3.73, were utilised in this study. To examine students' readiness for blended learning, descriptive statistics, including mean and standard deviation scores, were utilised. The mean score was in the form of logit scale rather than Likert-scale, which was transformed from the raw data score. Therefore, in terms of items, the bigger the logit score, the better students' readiness for blended learning.

Additionally, Differential Item Functioning (DIF) analysis was used to identify responses based on students' demographic profile (i.e. age, gender, ethnicity, field of study, and level of education). DIF analysis informs on the different types of responses based on the grouping of demographic characteristics, and therefore is the most suitable method of analysis for the study's objectives.

\section{RESULTS}

\section{Students' Readiness for Blended Learning}

Firstly, students' readiness for blended learning was analysed. Overall findings indicated that students were ready for the blended learning model of instruction as the overall mean score of +2.32 logit (SD $=1.79$ ) was higher than zero logit. According to Table 3 , among the six dimensions of readiness for blended learning, students rated highest on their technology skills, with a mean score of $\mathrm{M}=3.63$, $\mathrm{SD}=2.36$, but lowest on self-directed learning, with mean score of $\mathrm{M}=1.25, \mathrm{SD}=1.55$. The rest of the results on students' readiness for blended learning are summarised in Table 3 .

Table 3

Results of Students'Readiness for Blended Learning

\begin{tabular}{lcc}
\hline & Mean & Std. Deviation \\
\hline Readiness for Blended Learning (overall) & 2.32 & 1.79 \\
Technology Skills & 3.63 & 2.36 \\
\hline
\end{tabular}




\begin{tabular}{lcc}
\hline & Mean & Std. Deviation \\
\hline Attitude & 2.59 & 2.32 \\
Technology Availability & 2.47 & 1.80 \\
Computer and Internet Efficacy & 2.38 & 1.93 \\
Technology Usage & 2.16 & 1.65 \\
Self-directed Learning & 1.25 & 1.55 \\
\hline
\end{tabular}

\section{Differences Between Students' Demographic Factors and Readiness for Blended Learning}

Next, the differences between students' age, gender, ethnicity, field of study, and level of education, and their readiness for blended learning were analysed using Differential Item Functioning (DIF) analysis. The analysis for each of the five demographic factors mentioned is described below.

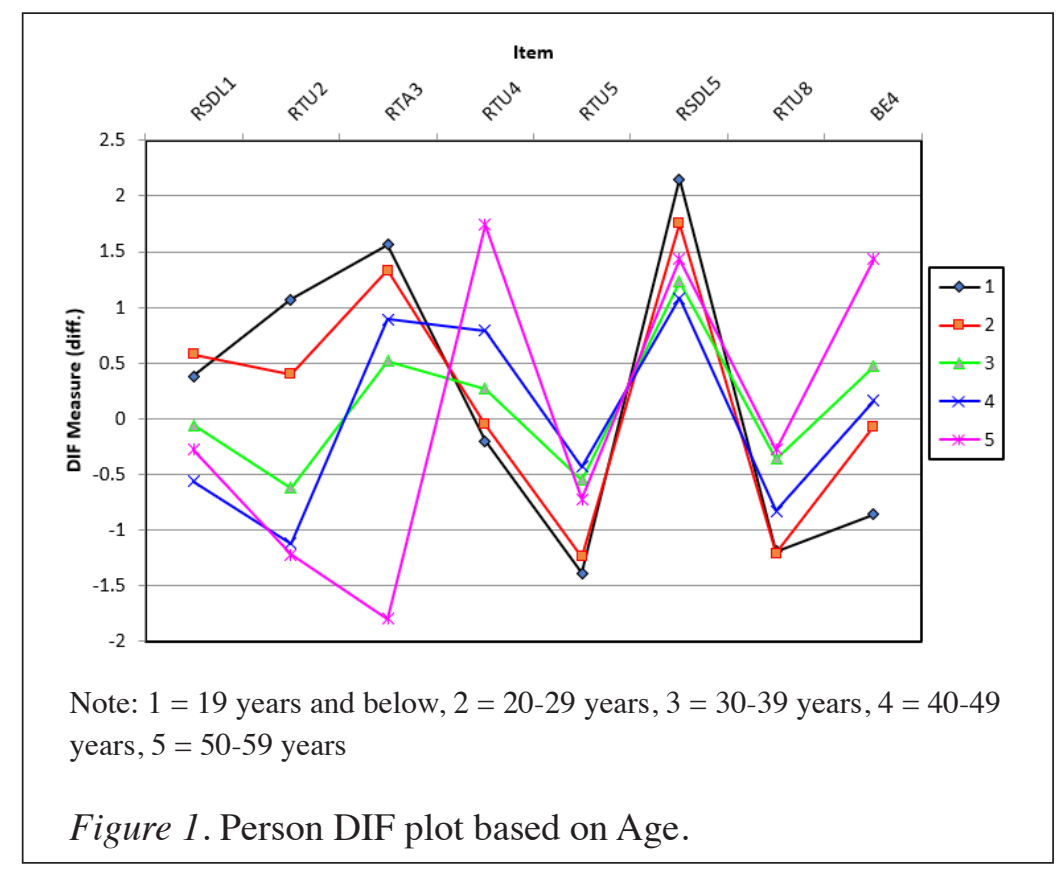

Figure 1 shows the DIF plot according to the respondents' age. In terms of students' age, eight items were identified to have significant differences according to a student's age group. For item RSDL1 (I am a highly independent learner), it was found that students aged 30 years old and above were more independent learners than 
students aged 29 years old and below. Similarly, the result for item RTU2 (I often use e-mail to communicate) indicated that students aged 30 years old and above more predominantly used e-mails for communication purposes compared to students aged 29 years old and below. However, item RTA3 (I have speakers for courses with video presentations) results indicated that students who were 50 to 59 years old were more likely to use speakers for their online learning. Findings for item RTU4 (I often use social networking sites to share information e.g. Facebook, Twitter, Instagram, Snapchat) were rather obvious, as students 50 to 59 years old seldom used social networking sites compared to younger students. Meanwhile, the results for item RTU5 (I often use instant messaging e.g. WhatsApp, Viber, WeChat, Line, Telegram) indicated that students under 29 years old use instant messaging more frequently than students of other age groups. Interestingly, the same age-group students felt that other online activities, as indicated in item RSDL5 (I am not distracted by other online activities when learning online e.g. Facebook, Gaming, Internet surfing), did not interfere with their online learning. Students aged 29 years and below also used gadgets more frequently to communicate, as indicated in item RTU8 (I often use mobile technologies e.g. Smartphone, Tablet to communicate). Lastly, for item BE4 (I do my assignments and submit it on time online), students under 20 years of age were more likely to complete and submit their assignments on time online compared to students aged 50 years and above.

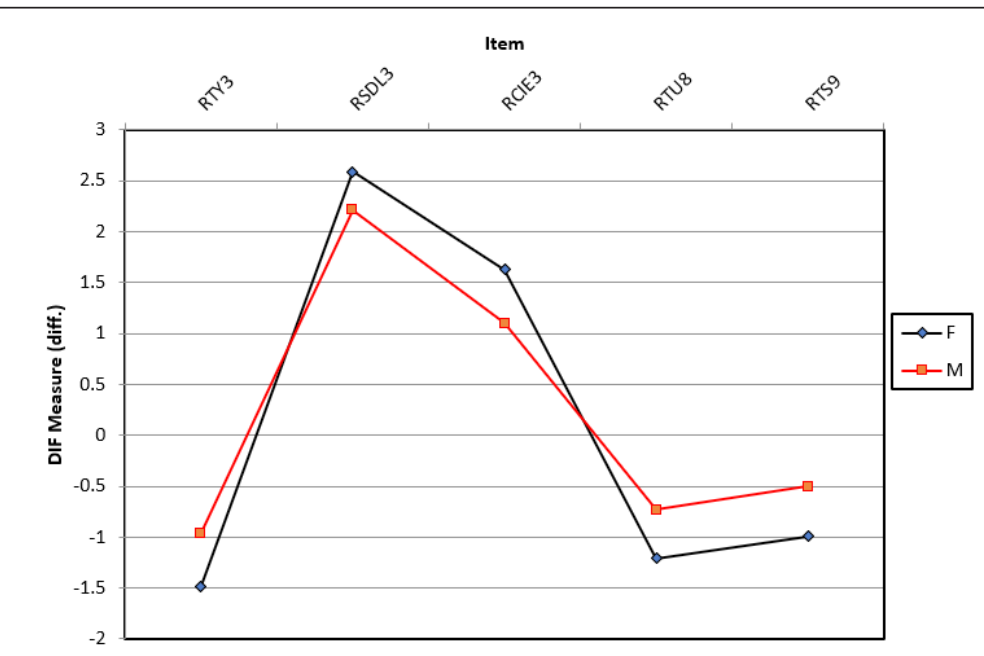

Note: $\mathrm{F}=$ Female, $\mathrm{M}=$ Male

Figure 2. Person DIF plot based on Gender. 
The Figure 2 illustrates the results of the DIF items based on gender. From the results, there were five items identified to have significant differences according to students' gender. For item RTY3 (I often use office software e.g. M.S. Word, PowerPoint, Excel), female students were more likely to use Microsoft Office software, and they also perceived themselves to be more skillful in it (RTS9: I know how to use Presentation software e.g. M.S. PowerPoint) compared to male students. Similarly, results for item RTU 8 (I often use mobile technologies e.g. Smartphone, Tablet to communicate) indicated that female students used mobile gadgets more frequently to communicate compared to male students. As for classroom instruction, item RSDL3 (I do not need direct lectures to understand materials), male students preferred lectures to understand learning materials better compared to their female counterparts. However, for item RCIE3 (I feel confident in posting questions in online discussions), male students were more confident in asking questions during online discussions compared to their female counterparts.

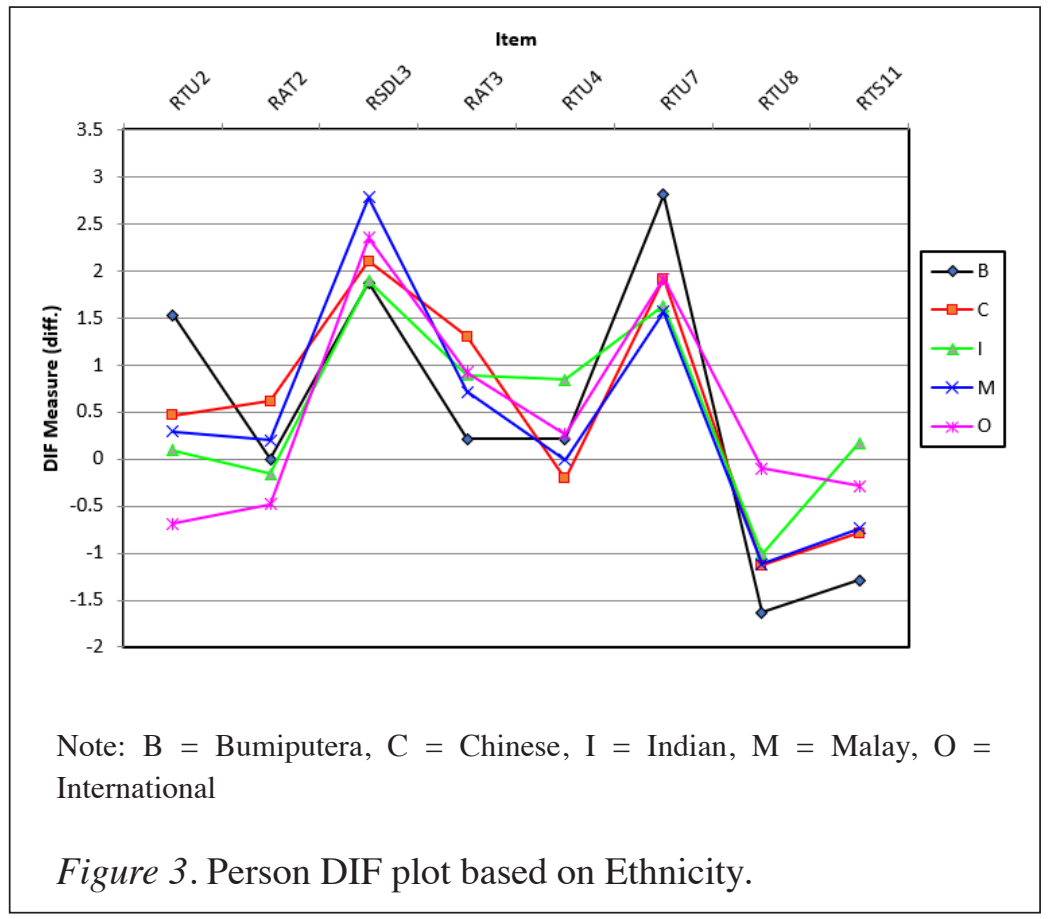

There were eight items that had DIF based on ethnicity. The first one is RTU2 (I often use e-mail to communicate) where it was found that Bumiputera students from Sabah and Sarawak were less likely to use e-mail to communicate compared to international students who used 
it more often. In terms of participation in blended learning instruction (RAT2: I am interested to participate in blended learning activities), Chinese students were the less likely to participate compared to students of other ethnicities. Results also showed that international students enjoyed participating in blended learning instruction. Malay students tended to prefer direct lectures more compared to students of other ethnicities, as per item RSDL3 (I do not need direct lectures to understand materials). Interestingly, Bumiputera students found blended learning tools easy to use, as seen for Item RAT3 (I find using blended learning technologies simple). Chinese students tended to use social media to share information more compared to all other ethnicities (RTU4: I often use social networking sites to share information e.g. Facebook, Twitter, Instagram, Snapchat). Bumiputera students from Sabah and Sarawak rarely used online learning software (RTU7: I often use learning management systems e.g. Blackboard, Moodle), but they were more likely to use their gadgets (RTU8: I often use mobile technologies e.g. Smartphone, Tablet to communicate) compared to students of other ethnicities. Finally, Indian students, for RTS11 (I know how to open several applications at the same time and move easily between them), found it more difficult to work simultaneously with multiple applications compared to the others. The results for all the DIF items according to ethnicity are summarised in Figure 3.

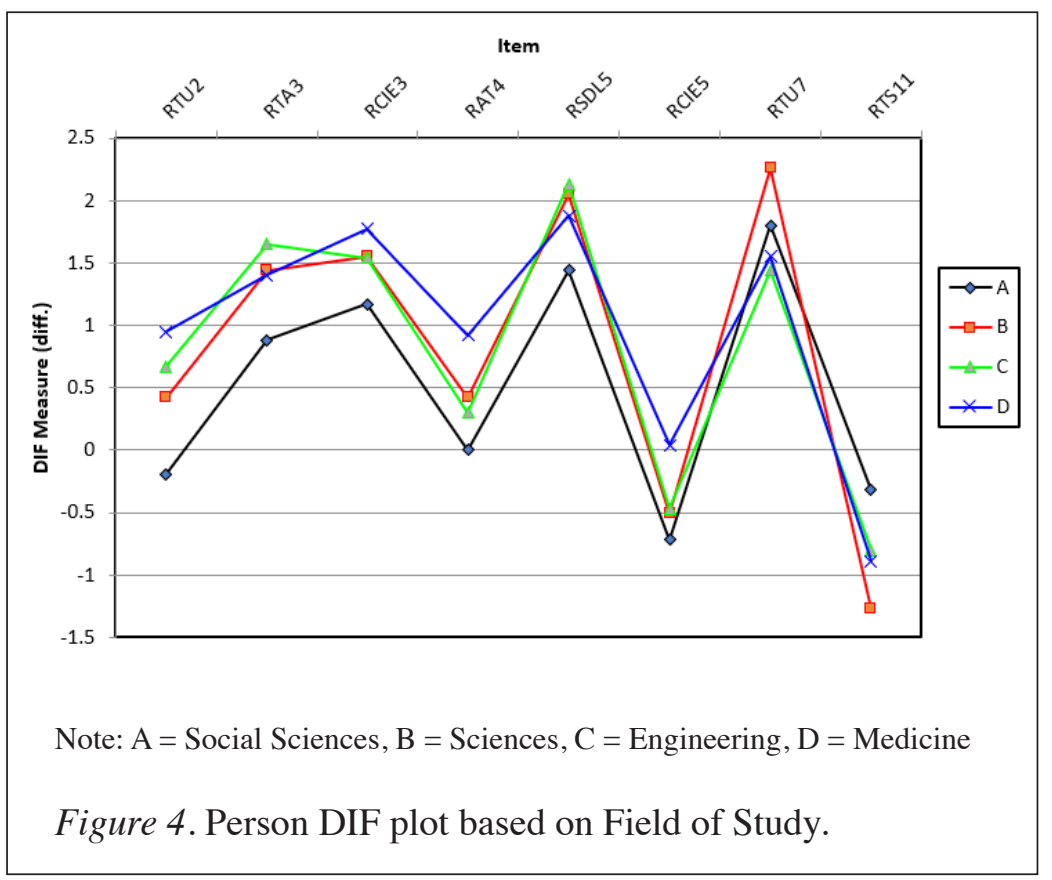


Referring to Figure 4, there were eight items that had DIF based on students' field of study. In terms of using e-mail to communicate (RTU2: I often use e-mail to communicate), the social science students used it more frequently compared to other students, and preferred speakers for their courses with video presentations as in item RTA3 (I have speakers for courses with video presentations). Social science students were also more confident when they posted questions in online discussions (RCIE3: I feel confident in posting questions in online discussions). As for RAT4 (I would recommend blended learning as one of the alternatives for the traditional teaching-learning approaches), social science students tended to agree, but medical students tended to disagree. Interestingly, social science students were more focused during online learning, as shown for item RSDL5 (I am not distracted by other online activities when learning online e.g. Facebook, Gaming, Internet surfing), compared to students in other fields of study. When responding to RCIE5 (Ifeel confident in performing the basic functions of Presentation software e.g. MS PowerPoint), medical students were found to be slightly less confident, whereas social science students felt that they were more confident. Findings also showed that engineering students used the LMS system more frequently compared to students in other fields of study, as in the results for item RTU7 (I often use learning management systems e.g. Blackboard, Moodle). When dealing simultaneously with multiple applications (RTS11: I know how to open several applications at the same time and move easily between them), science students did not have much problem doing so compared to students in other fields of study.

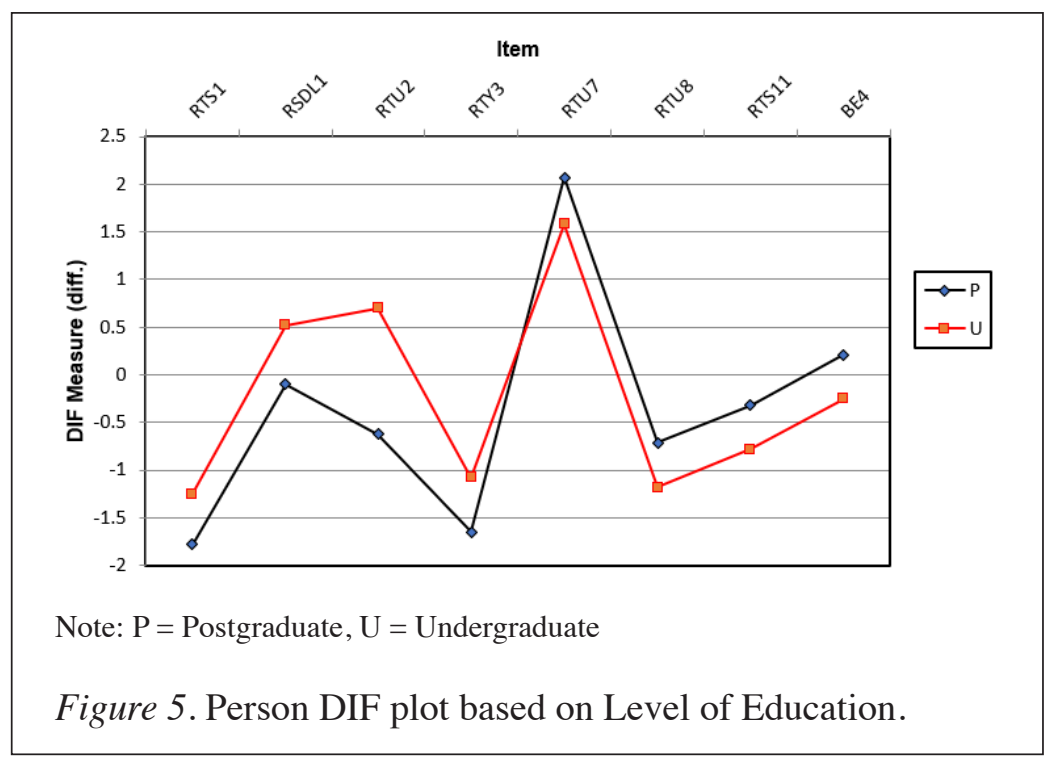


According to students' level of education, eight items recorded a DIF, shown in Figure 5. Interestingly, basic functions of the computer and laptop (RTS1: I know the basic functions of computer/laptop and its peripherals like the printer, speaker, keyboard, mouse etc.) were understood more easily by postgraduate students compared to the undergraduates. When asked about their perception of themselves as an independent learner (RSDL1: I am a highly independent learner), postgraduate students felt that they were more independent compared to undergraduate students. Postgraduate students also used e-mail (RTU2: I often use e-mail to communicate), and MS Office software (RTY3: I often use office software e.g. M.S. Word, PowerPoint, Excel) more often compared to undergraduate students. Regarding responses to RTU7 (I often use learning management systems e.g. Blackboard, Moodle), both groups rarely used these systems, while for RTU8 (I often use mobile technologies e.g. Smartphone, Tablet to communicate.), undergraduate students used mobile technologies slightly more compared to postgraduate students. As for RTS11 ( know how to open several applications at the same time and move easily between them), undergraduate students could perform this better than postgraduate students. Finally, undergraduate students used online platforms to complete their assignments and submit them on time better than postgraduate students (BE4: I do my assignments and submit it on time online).

\section{DISCUSSION}

This study aimed to investigate what the level of students' readiness for blended learning was, and specifically assess any significant differences in students' readiness for blended learning based on gender, age, ethnicity, field of study, and level of education. The outcomes of the findings showed that students at this particular higher education institution were ready for e-learning, and had the required technological skills. An explanation for the students possessing the much-needed technological skills could be due to prior training on information technology, and exposure to technological innovations which made them tech-savvy. However, in the areas of technology usage, technology availability, computer and internet efficacy, and attitude, students required a few improvements. Students had a low level of readiness in self-directed learning compared to other dimensions, indicating that some work needs to be done within the area of self-directed learning in order to make students ready for 
e-learning. The low rating on self-directed learning could be due to the reason that students, in the context of a Malaysian higher education institute, were not comfortable with e-learning, and preferred traditional learning (Win \& Wynn, 2015). Findings in this study corroborated with the results of another study, where students in a higher education institution rated average for self-directed learning, aside from technology availability and skills (Rasouli, Rahbania \& Attaran, 2016). This indicates that universities should draw elaborate plans to enhance students' readiness in terms of indicators such as technology usage, technology availability, computer and internet efficacy, self-directed learning, and attitude. In an e-learning environment, students need access to technological tools, software and the internet, which enables them to be interested in engaging in the blended learning model of instruction. This view was supported by Aboderin (2015), who revealed that the barriers impinging on the implementation of blended learning in developing countries were internet connectivity, computer and software equipment.

The DIF analysis showed that there were differences in demographic variables on students' e-learning readiness. In terms of age, mature students felt more independent compared to other age groups, such as those below 29 years. Older students tended to use e-mail more often, and were more likely to use speakers, whereas younger students preferred headsets to listen to audio or sound while watching videos. Students below 29 years of age were much more connected to social media for instant messaging, and used mobile technologies or gadgets compared to students between the ages of 30 to 59 years old. The results of this study revealed that learners of all the age groups did not experience disturbances by other online activities while they engaged in online learning. Generally, younger students were more comfortable with mobile technologies compared to older students, as they are from a technology savvy generation.

In terms of gender, findings showed significant difference in five items. These items indicated that females used mobile technologies and gadgets, more often than males. This could be due to a higher use of social networks among female students than male (Thorell, Fridorff-Jens, Lassen, Lange \& Kayser, 2015). Female students also used Office software more often, especially when they perceived themselves to be more skillful in using Microsoft PowerPoint than males. Similarly, Ikolo and Okiy (2012) stated that more females used Microsoft Word than males among clinical medical students. 
Previous findings also reported that males significantly differred from females on the effectiveness of e-learning (Islam, Abdul Rahim, Liang \& Momtaz, 2011). Results of another study revealed a significant mean difference in learning preferences based on students' gender (Lau \& Shaikh, 2012). On the other hand, a study conducted outside of Malaysia showed that male students were more comfortable with technology, and preferred technology for learning (Naresh, Reddy \& Pricilda, 2016). However, a contrasting finding showed that there was no significant difference between male and female students in their readiness for e-learning (Rasouli, Rahbania $\&$ Attaran, 2016). With regards to instruction, unlike female students, male students preferred direct lecture; however, male students were more confident in asking questions during online discussions. This can be due to the fact that male students have more confidence in using technology for learning than female students (Yau \& Cheng, 2012). Additionally, male students may have a more positive belief on relying on technology for interactive learning purposes, and are more familiar with advanced tools. Some similar studies reported that male students were more excited to participate in online activities compared to female students (Win \& Wynn, 2015), while other studies showed that there was no significant difference between gender, and computer self-efficacy, technical skills, and attitude towards computers (Lau \& Shaikh, 2012). Females using mobile gadgets and Microsoft Office more often than males indicated that they have a positive attitude and high motivation to use technology (Yau \& Cheng, 2012).

In terms of ethnicity, findings of this study revealed that international students participated more actively in blended learning activities, whereas Chinese students were the least likely of all the ethnicities. This finding is supported by other studies reporting the significant difference in learning preference and attitude towards computers based on ethnicity (Lau \& Shaikh, 2012). International students also used e-mail more often to communicate. However, Bumiputera students from Sabah and Sarawak were less likely to use e-mail to communicate. Additionally, students from Sabah and Sarawak used online learning software rarely although they used their gadgets more often. Chinese students tended to use social media to share information more compared to other ethnic groups, and Indian students used it the least. Moreover, Indian students also found it more difficult to use multiple applications or multi-window screens simultaneously in a blended learning environment. These findings 
contrast with the findings of Islam et al. (2011), who claimed that race did not have any influence on e-learning effectiveness.

In terms of the field of study, social science students preferred using e-mail to communicate, while medical students preferred it the least. Social science students were also more confident when they posted questions in online discussions, and they recommended blended learning as one of the alternatives for the traditional approach to instruction. Interestingly, social science students were also more focused during online learning. Unfortunately, medical students were slightly less confident in using presentation software like PowerPoint compared to the social science students. Nevertheless, this finding does not mean that medical students lack confidence as a different study indicated that they have extremely good familiarity and skills with MS PowerPoint (Robabi \& Arbabisarjou, 2015). When dealing with a multi-window screen situation, science students did not face any problems compared to other groups of students. In contrast, social science students had the poorest technical skills to deal with a multi-window screen situation. A study showed similar findings where science students were more comfortable using technology for learning while arts students did not prefer this method of learning (Rasouli, Rahbania \& Attaran, 2016). Science students using different types of technological devices during their practical experiments, and the inclusion of students studying information technology in the category could possibly be the reason for science students being more comfortable with using technology compared to those in the social sciences. Yet, there were studies which reported that courses or fields of study did not have a significant difference in students' readiness (Rasouli, Rahbania \& Attaran, 2016).

In terms of level of education, postgraduate students easily understood the basic functions of a computer and laptop, and they were more independent learners compared to undergraduate students. Postgraduate students also used e-mail often to communicate, and they were the group of students who always used MS Office software. Interestingly, they preferred blended learning as an alternative to the typical teaching and learning approach more compared to undergraduate students. It can be interpreted here that postgraduate students have a higher computer literacy in understanding and utilising information technology, and they are more mature and independent learners. 
These findings were similar to some findings that reported that postgraduate students had a higher level of readiness than undergraduate students (Rasouli, Rahbania \& Attaran, 2016), and students with a higher level of education tended to be more computer literate and ready to use technology in their learning (Islam et al., 2011). However, further findings in this study showed that both postgraduate and undergraduate students rarely used online learning, but undergraduate students used it more compared to postgraduate students. The researchers assume that the findings are very much relevant to the implementation of blended learning across different courses as more undergraduate programmes offer blended learning courses than postgraduate programmes. This inference is supported by Salim et al. (2018), where in a medicine postgraduate course, implementation of blended learning is scarce, and most of the implementations are at the undergraduate level. More importantly, undergraduate students were more likely to have a better experience with different types of online learning activities (Farley et al., 2015).

\section{CONCLUSION}

The implementation of blended learning became inevitable in the teaching and learning process of universities, where one would "redefine higher education institutions as being learning centered, and facilitate a higher learning experience" (Garrison \& Kanuka, 2004, p. 104). However, the e-learning readiness of students must be taken into consideration in the movement towards a blended learning model of instruction. It would be unwise for universities to impose a blended learning environment on students without first identifying their readiness and needs.

The findings of this study revealed a moderate level of e-learning readiness, which suggests the importance of making students aware of the technology in e-learning, and the availability of technological resources. The DIF analysis showed that there was a significant difference based on demographic variables such as age, gender, ethnicity, field of study, and level of education towards students' readiness for e-learning.

However, this study has its limitations as well. Firstly, the study concentrated only on one public higher education institution in Kuala Lumpur, Malaysia. Therefore, future studies should include 
public higher education institutions, while also considering both the students' and lecturers' perspectives. Secondly, the current study is limited to a quantitative cross-sectional research design, where data were collected from 235 undergraduate and 131 postgraduate students from various fields of study. As such, future studies could involve larger sample sizes to ensure the data are presentable and generalisable. Furthermore, interviews are needed to explore further the possible reasons to explain such findings.

In consideration of these findings, higher education institutions should have a re-prioritisation of fund allocations towards identifying students' characteristics, and their readiness for a blended learning environment. Future blended learning research may look more specifically into how pedagogy and course designs affect students' current engagement in a blended learning model of instruction. Besides that, what specific blended learning strategies are most effective for different subjects or fields of study, and the various learner types would be valuable areas for exploration. In addition, support systems and training programmes need to be in place to ease the transitional process from traditional methods to a blended learning model of instruction (Rasouli, Rahbania \& Attaran, 2016). Instructors must know how to be facilitators of learning, assessors of student competencies, and advocates of self-explored learning (Kumar, 2017).

\section{ACKNOWLEDGEMENT}

This research was funded by the Bantuan Kecil Penyelidikan (BKP) (BK031-2017) grant under the University of Malaya.

\section{REFERENCES}

Abbas K, Masoud AM, Ali K. (2011). The role of readiness factors in Elearning outcomes: An empirical study. Computers \& Education, 57(3):1919-1929.

Aboderin, O. S. (2015). The challenges and prospects of e-learning in National Open University of Nigeria. Journal of Education and Learning, 9(3), 207-216.

Al-Busaidi, K. A. (2013). An empirical investigation linking learners' adoption of blended learning to their intention of full e-learning. Behaviour \& Information Technology, 32(11), 1168-1176. 
Alkhanak, S.A.K., \& Azmi, I.A.G. (2011). Information technology usage and attitudes towards online resources - Students perspective. African Journal of Business Management, 5(7), 2582-2589.

Anene, J., Imam, H., \& Odumuh, T. (2014). Problem and prospect of e-learning in Nigerian universities. International Journal of Technology and Inclusive Education, 3(2), 320-327

Azhari, F. A., \& Ming, L. C. (2015). Review of e-learning practice at the tertiary education level in Malaysia. Indian Journal of Pharmaceutical Education and Research, 49(4), 248-257.

Azizan, F.Z. (2010). Blended learning in higher education institution in Malaysia. Proceedings of Regional Conference on Knowledge Integration in ICT, Selangor, 454-466.

Baldwin-Evans, K. (2006). Key steps to implementing a successful blended learning strategy. Industrial and Commercial Training, 38(3), 156-163.

Bernard, M. B., Borokhovski, E., Schmid, R. F., Tamim, R. M., \& Abrami, Ph. C., (2014). A meta-analysis of blended learning and technology use in higher education: from the general to the applied. Journal of Computing in Higher Education, 26(1), 87-122.

Bond, T.G., \& Fox, C.M. (2015). Applying the Rasch Model, Fundamentals Measurement in the Human Sciences (3rd edition). New York: Routledge.

Boone, W.J., Staver, J.R., \& Yale, M.S. (2014). Rasch Analysis in the Human Sciences. Dordrecht: Springer.

Chu, R., \& Tsai, C. C. (2009). Self-directed learning readiness, Internet self-efficacy and preferences towards constructivist Internet-based learning environments among higher-aged adults. Journal of Computer Assisted Learning, 25(5), 489501.

Doiron, R., \& Asselin, M. (2011). Exploring a new learning landscape in tertiary education. New Library World, 112(5/6), 222-235.

Drysdale, J. S., Graham, C. R., Spring, K. J., \& Halverson, L. R. (2013). An analysis of research trends in dissertations and theses studying blended learning. The Internet and Higher Education, 17, 90-100.

El-Gayar,O.,Moran, M., \& Hawkes, M.(2011). Students'Acceptance of tablet PCs and implications for educational institutions. Educational Technology \& Society, 14(2), 58-70.

Embi, M. A., Abdul Wahab, Z., Sulaiman, A. H., Atan, H., Ismail, M., \& Mohd Nordin, N. (2011). e-Learning in Malaysian higher education institutions: Status, trends \& challenges. 
Kuala Lumpur, Malaysia: Department of Higher Education, Ministry of Higher Education Malaysia.

Farley, H, Murphy, A, Johnson, C, Carter, B, Lane, M, Midgley, W, Hafeez-Baig, A, Dekeyser, S and Koronios, A. (2015). How do students use their mobile devices to support learning? A case study from an Australian Regional University. Journal of Interactive Media in Education, 14(1), 1-13.

Fisher, W.P. Jr. (2007). Rating scale instrument quality criteria. Rasch Measurement Transactions, 21(1), 1095.

Garrison, D. R., \& Anderson, T. (2003). E-learning in the 21st century: A framework for research and practice. London and New York: RoutledgeFalmer

Garrison, D. R., \& Kanuka, H. (2004). Blended learning: Uncovering its transformative potential in higher education. Internet and Higher Education, 7(2), 95-105.

George, P. P., Papachristou, N., Belisario, J. M., Wang, W., Wark, P. A., Cotic, Z., ... \& Musulanov, E. M. (2014). Online eLearning for undergraduates in health professions: A systematic review of the impact on knowledge, skills, attitudes and satisfaction. Journal of Global Health, 4(1), 1-17.

González-Gómez, D., Jeong, J. S., Rodríguez, D. A., \& CañadaCañada, F. (2016). Performance and perception in the flipped learning model: an initial approach to evaluate the effectiveness of a new teaching methodology in a general science classroom. Journal of Science and Education Technology, 25(3), 450-459.

Graham, C. R. (2013). Emerging practice and research in blended learning. In M. G. Moore (Ed.), Handbook of distance education (pp. 333-350). (3rd ed.). New York, NY: Routledge.

Graham, C. R., \& Robison, R. (2007). Realizing the transformational potential of blended learning: Comparing cases of transforming blends and enhancing blends in higher education. In A. G. Picciano \& C. D. Dziuban (Eds.), Blended learning: Research perspectives. (pp. 83-110). Needham, MA: Sloan Consortium.

Halverson, L. R., Graham, C. R., Spring, K. J., \& Drysdale, J. S. (2012). An analysis of high impact scholarship and publication trends in blended learning. Distance Education, 33(3), 381413.

Harris, P., Connolly, J., \& Feeney, L. (2009). Blended learning: Overview and recommendations for successful implementation. Industrial and Commercial Training, 41(3), 155-163.

Heidi, Y. J. T., \& Neo, M. (2015). Exploring the use of authentic learning strategies in designing blended learning environments. 
Journal of Science and Technology Policy Management, 6(2), 127.

Howard, S.B. (2009). The benefits of face-to-face interaction in the online freshman composition course. Journal of Online Learning and Teaching, 5(4), 685-697.

Hussein, I. (2010). Measuring students'e-readiness for e-learning at Egyptian faculties of tourism and hotels. The 6th International Scientific Conference on E-Learning and Software for Education. Bucharest, Romania, 2010.

Hussin H, Bunyarit F, \& Hussein R. (2009). Instructional design and e-learning: Examining learners' perspective in Malaysian institutions of higher learning. Campus-Wide Information System, 26(1), 4-19.

Ikolo, V. E., \& Okiy, R. B. (2012). Gender differences in computer literacy among clinical medical students in selected Southern Nigerian Universities. Library Philosophy and Practice (e-journal). 745 .

Islam, M.A.,Abdul Rahim, N.A., Liang, T.C., \& Momtaz, H.(2011). Effect of demographic factors on e-learning effectiveness in a higher learning institution in Malaysia. International Education Studies, 4(1), 112-121.

Kaur, N. (2014). Teacher-Led Initiatives in Supporting Learner Empowerment among Malay Tertiary Learners. Malaysian Journal of Learning and Instruction, 11, 101-126.

Kumar, A. (2017). E-learning and blended learning in orthodontic education. APOS Trends in Orthodontics, 7(4), 188.

Lau, C. Y., \& Shaikh, J. M. (2012). The impacts of personal qualities on online learning readiness at Curtin Sarawak Malaysia (CSM). Educational Research and Reviews, 7(20), 430-444.

Lim, D. H., \& Morris, M. L. (2009), Learner and Instructional Factors Influencing Learning Outcomes within a Blended Learning Environment. Educational Technology \& Society, 12 (4), 282-293.

Linarce, J.M. (2012). A user's guide to Winsteps Ministeps Raschmodel computer programs [version 3.74.0], Chicago IL: Winstep.com.

Lopez-Perez, V.M., Perez-Lopez, C.M., \& Rodriguez-Ariza, L. (2011). Blended learning in higher education: Students' perceptions and their relation to outcomes. Computers \& Education, 56(3), 818-826.

MacKeogh, K. (2003), Student Perceptions of the use of ICTs in European Education: Report of a Survey, Dublin City University,Dublin. Retrieved from: /www.oscail.ie/academic/ picture.php. 
Margaryan, A., Bianco, M., \& Littlejohn, A. (2015). Instructional quality of massive open online courses (MOOCs). Computers \& Education, 80, 77-83.

Martinez, M. \& Jagannathan, S. (2012). Learning solution: Moodle: A low-cost solution for successful e-learning. Retrieved from http://www.learningsolutionsmag.com/articles/71/moodlealow-cost-solution-for-successful-e-learning

Moore, J.L., Dickson-Deane, C., \& Galyen, K. (2011), E-Learning, online learning, and distance learning environments: Are they the same? Internet Higher Education, 14(2), 129-35.

Mosadegh, H., Kharazi, K., \& Bazargan, A. (2011). Conducting feasibility of e-learning in gas companies in Yazd province. Journal of Science and Technology Information, 3, 547-569

Naresh, B., Reddy, B.S., \& Pricilda, U. (2016). A study on the relationship between demographic factor and e-learning readiness among students in higher education. Sona Global Management Review, 10(4), 1-11.

Northey, G., Bucic, T., Chylinski, M., \& Govind, R., (2015). Increasing Student Engagement Using Asynchronous Learning. Journal of Marketing Education, 37(3), 171-180.

Orton-Johnson, K., (2009). 'I've stuck to the path I'm afraid':exploring student non-use of blended learning. British Journal of Educational Technology, 40 (5), 837-847.

Paechter, M., \& Maier, B .. (2010). Online or face-to-face? Students' experiences and preferences in e-learning. Internet and Higher Education, 13(4), 292-297.

Panyajamorn, T., Suthathip, S., Kohda, Y., Chongphaisal, P., \& Supnithi, T. (2018). Effectiveness of E-learning design and affecting variables in Thai public schools. Malaysian Journal of Learning and Instruction, 15 (1), 1-34.

Park, S.Y. (2009). An analysis of the technology acceptance model in understanding university students' behavioral intention to use e-learning. Educational Technology and Society, 12(3), 150-162.

Pellas, N., \& Kazandis, I., (2015). On the value of second life for students' engagement in blended and online courses: A comparative study from the Higher Education in Greece. Education and Information Technologies, 20(3), 445-466.

Rasouli, A., Rahbania, Z., \& Attaran, M. (2016). Students' readiness for E-learning application in higher education. Malaysian Online Journal of Educational Technology, 4(3), 51-64.

Rhee, V. D., B., Verma, R., Plaschka, G. R., \& Kickul, J. R. (2007). Technology readiness, learning goals, and eLearning: 
searching for synergy. Decision Sciences Journal of Innovative Education, 5(1), 127-149.

Robabi, H., \& Arbabisarjou, A. (2015). Computer literacy among students of Zahedan University of Medical Sciences. Global Journal of Health Science, 7(4), 136-142.

Ryan, S., Kaufman, J., Greenhouse, J., Joel; She, R. and Shi, J., (2016). The effectiveness of blended online learning courses at the community college level. Community College Journal of Research and Practice, 40(4), 285-298.

Salim, H.,Lee, P. Y., Ghazali, S. S., Ching, S.M.,Ali, H., Shamsuddin, N. H., Mawardi, M., Kassim, P. S. J. \& Dzulkarnain, D. H. A. (2018). Perceptions toward a pilot project on blended learning in Malaysian family medicine postgraduate training: a qualitative study. BMC medical education, 18(1), 206.

Seraji, F. (2013). Identification and categorising the skills needed for the virtual student. Journal of Training and Learning Researches, 2, 75-90

Seraji, F., \& Yarmohammadi, M. (2010). Preparation and readiness assessment validate incoming e-Learning courses. Journal of Educational Measurement, 2(32), 127-149.

Shahnaz, S. M. F., \& Hussain, R. M. R. (2016). Designing Instruction for Active and Reflective Learners in the Flipped Classroom. Malaysian Journal of Learning and Instruction, 13(2), 147173.

Southard, S., Meddaugh, J., \& France-Harris, A. (2015). Can SPOC (self-paced online course) live long and prosper? A comparison study of a new species of online course delivery. Online Journal of Distance Learning Administration, 18. Retrieved from http://www.westga.edu/ distance/ojdla/

Sumintono, B., \& Widhiarso, W. (2014). Aplikasi Model Rasch untuk Penelitian Ilmu-Ilmu Sosial (edisi revisi) [Application of rasch modelling in social science research, revised edition]. Cimahi: Trimkom Publishing House.

Starenko, M., Vignare, K., \& Humbert, J. (2007). Enhancing student interaction and sustaining faculty instructional innovations through blended learning. In A.G. Picciano and C.D. Dziuban (Eds.), Blending Learning: Research Perspectives (pp. 161178). Needham, MA: Sloan Consortium.

Tayebinik, M., \& Puteh, M. (2012). Blended Learning or E-learning? International Magazine on Advances in Computer Science and Telecommunications, 3(1), 103-110.

Thorell, M., Fridorff-Jens, P. K., Lassen, P., Lange, T., \& Kayser, L. (2015). Transforming students into digital academics: 
a challenge at both the individual and the institutional level. $B M C$ medical education, 15(1), 48.

Vaughan, N. (2007). Perspectives on blended learning in higher education. International Journal on E-Learning, 6(1), 81-94.

Wang, M. J. (2010). Online collaboration and offline interaction between students using asynchronous tools in blended learning. Australasian Journal of Educational Technology, 26(6), 830-846.

Watson, J. (2008). Promising practices in online learning: Blending learning: The convergence of online and face-to-face education. North American Council for Online Learning.

Win, N.L., \& Wynn, S.D. (2015). Introducing blended learning practices in our classrooms. Journal of Institutional Research in South East Asia, 12(2), 17-27.

Yau, H. K., \& Cheng, A. L.F. (2012). Gender difference of confidence in using technology for learning. Journal of Technology Studies, 38(2), 74-79.

Yukselturk, E., \& Bulut, S. (2007). Predictors for student success in an online course. Journal of Educational Technology \& Society, 10(2), 71-83. 


\section{Appendix 1. Unidimensionality}

Table of STANDARDIZED RESIDUAL variance (in Eigenvalue units) -- Empirical -- Modeled

\begin{tabular}{|c|c|c|c|}
\hline Total raw variance in observations & $=105.0$ & $100.0 \%$ & $100.0 \%$ \\
\hline Raw variance explained by measures & $=48.0$ & $45.7 \%$ & $47.2 \%$ \\
\hline Raw variance explained by persons & 23.8 & $22.7 \%$ & $23.4 \%$ \\
\hline Raw Variance explained by items & 24.2 & $23.1 \%$ & $23.8 \%$ \\
\hline Raw unexplained variance (total) & 57.0 & $54.3 \%$ & $100.0 \% 52.8 \%$ \\
\hline Unexplned variance in 1 st contrast & 9.5 & $9.1 \%$ & $16.7 \%$ \\
\hline Unexplned variance in $2 \mathrm{nd}$ contrast & 4.3 & $4.1 \%$ & $7.6 \%$ \\
\hline Unexplned variance in 3 rd contrast & 2.6 & $2.4 \%$ & $4.5 \%$ \\
\hline Unexplned variance in 4 th contrast & 2.1 & $2.0 \%$ & $3.7 \%$ \\
\hline Unexplned variance in 5 th contrast & 1.8 & $1.7 \%$ & $3.1 \%$ \\
\hline
\end{tabular}

Appendix 2. Rating Scale Analysis

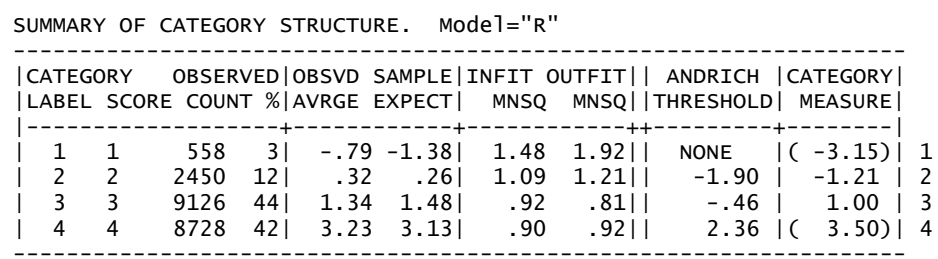

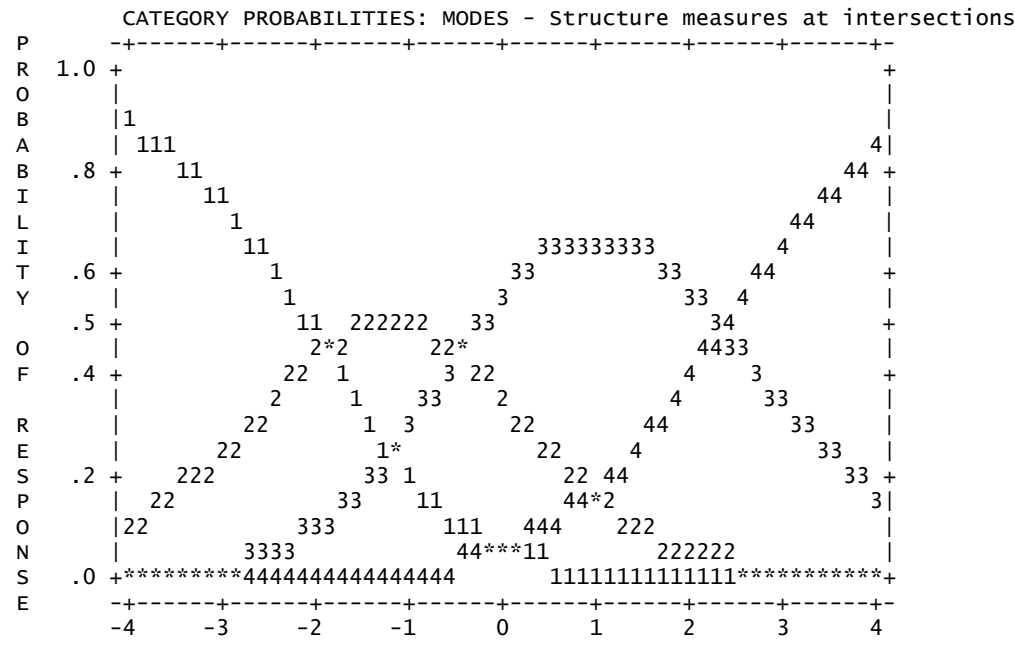


Appendix 3. Summary Statistics

SUMMARY OF 366 MEASURED (EXTREME AND NON-EXTREME) Person

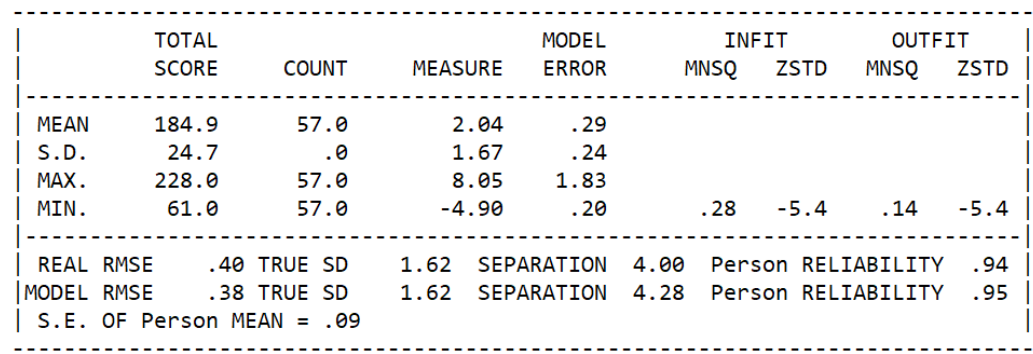

Person RAW SCORE-TO-MEASURE CORRELATION $=.93$

CRONBACH ALPHA (KR-20) Person RAW SCORE "TEST" RELIABILITY = .97

SUMMARY OF 41 MEASURED (NON-EXTREME) Item

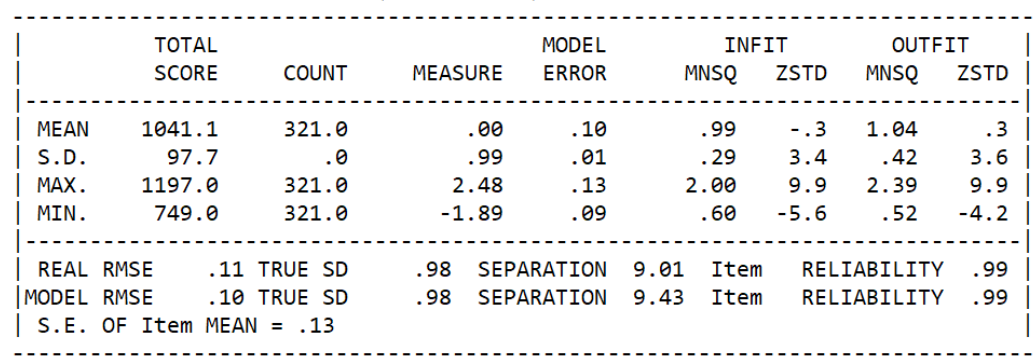

